\title{
Mechanical Integrity and Failure Analysis of Photovoltaic Modules under Simulated Snow Loads Using Pneumatic Airbag Setup
}

\author{
Nouman Ali Shah ${ }^{1,2}{ }^{(0}$, Rizwan M. Gul ${ }^{2}$, Zafar Hayat Khan ${ }^{3 *}$ \\ ${ }^{1}$ State Key Laboratory of Polymer Materials Engineering, College of Polymer Science and Engineering, Sichuan University, \\ Chengdu, China \\ ${ }^{2}$ Department of Mechanical Engineering, University of Engineering and Technology, Peshawar, Pakistan \\ ${ }^{3}$ State Key Laboratory of Hydraulics and Mountain River Engineering, College of Water Resource and Hydropower, \\ Sichuan University, Chengdu, China \\ Email: alinouman330@yahoo.com,rgul@uetpeshawar.edu.pk, ^zhkhan@scu.edu.cn
}

How to cite this paper: Shah, N.A., Gul, R.M. and Khan, Z.H. (2022) Mechanical Integrity and Failure Analysis of Photovoltaic Modules under Simulated Snow Loads Using Pneumatic Airbag Setup. Journal of Power and Energy Engineering, 10, 1-13. https://doi.org/10.4236/jpee.2022.101001

Received: November 19, 2021

Accepted: January 8, 2022

Published: January 11, 2022

Copyright (๑) 2022 by author(s) and Scientific Research Publishing Inc. This work is licensed under the Creative Commons Attribution International License (CC BY 4.0).

http://creativecommons.org/licenses/by/4.0/

\begin{abstract}
Photovoltaic (PV) modules have emerged as an ideal technology of choice for harvesting vastly available renewable energy resources. However, the efficiency of PV modules remains significantly lower than that of other renewable energy sources such as wind and hydro. One of the critical elements affecting a photovoltaic module's efficiency is the variety of external climatic conditions under which it is installed. In this work, the effect of simulated snow loads was evaluated on the performance of PV modules with different types of cells and numbers of busbars. According to ASTM-1830 and IEC-1215 standards, a load of $5400 \mathrm{~Pa}$ was applied to the surface of PV modules for 3 hours. An indigenously developed pneumatic airbag test setup was used for the uniform application of this load throughout the test, which was validated by load cell and pressure gauge. Electroluminescence (EL) imaging and solar flash tests were performed before and after the application of load to characterize the performance and effect of load on PV modules. Based on these tests, the maximum power output, efficiency, fill factor and series resistance were determined. The results show that polycrystalline modules are the most likely to withstand the snow loads as compared to monocrystalline PV modules. A maximum drop of $32.13 \%$ in the power output and a $17.6 \%$ increase in series resistance were observed in the modules having more cracks. These findings demonstrated the efficacy of the newly established test setup and the potential of snow loads for reducing the overall performance of PV module.
\end{abstract}

\section{Keywords}

Photovoltaic Modules, Pneumatic Testing Setup, Mechanical Integrity, 
Electroluminescence Testing, Electrical Performance

\section{Introduction}

Sustainable development in energy is a need in the rapidly growing world, which is not possible without harvesting renewable resources. Solar energy has emerged as a top source with a $33 \%$ share in the renewable energy market across the world [1] [2]. Photovoltaic (PV) modules are one of the most widely used systems for harnessing solar energy [3]. According to the International Energy Agency (IEA), $\mathrm{PV}$ is the fastest growing renewable energy technology with $3 \%$ of the gross electricity production and is estimated to surpass $600 \mathrm{GW}$ of global installations by 2019 [4]. In addition, it is also predicted that it will have 2.5 times increase by 2025, which will make the total PV installed capacity exceed 1 TW [5]. PV solar technologies are mainly dominated by crystal silicon solar cells, covering $80 \%$ of the total world installed capacity. Although newer approaches using thin-films, cadmium telluride/cadmium sulfide ( $\mathrm{CdTe} / \mathrm{CdS}$ ), organic photopolymers, and composite devices have come out to meet the anticipated demand for energy and boost the efficiency of the already existing technology [6].

The first generation of silicon solar cells PV modules are made of monocrystalline and polycrystalline silicon wafers. It has been reported to have a cell efficiency of over $25 \%$, but there is a drop in performance with time [7]. As PV modules are installed outdoors, they are exposed to extreme ambient conditions like snow, wind, hail, fluctuating temperatures, and dust [4] [8]. Out of these, snow and wind impose mechanical load on the surface of PV modules, which can detrimentally affect its performance [9] [10] [11]. These mechanical loads can be established as static and dynamic loads. Mechanical testing of PV modules is performed according to IEC-61215 [12] and ASTM 1830 standards, to analyze the PV modules for their mechanical integrity and performance over its life [13].

Different types of test setups are being used to apply these simulated loads on the surface of PV modules, including suction cups, bricks, and sandbags [14] [15]. However, there are certain drawbacks associated with these setups [16] [17]. For example, the application of load is not uniform on the surface of the module in the suction cups and bricks mechanism of testing. While the heterogeneous density and uneven distribution of sand are the major problems in applying load by this method. Hence, there is a dire need to explore other stateof-the-art methods for the application of simulated loads on PV modules [18] [19].

In this study, we have indigenously designed and developed a pneumatic airbag test setup to apply a uniform static load on the surface of PV modules. To validate the effectiveness of the novel test setup, monocrystalline and polycrystalline PV modules with different numbers of busbars were tested. In addition, the mechanical integrity and electrical performance parameters like power, efficiency, fill factor and series resistance of the PV modules were compared before 
and after application of load. The results showed the efficacy of the test setup and induced many cracks during the testing, proving that it can be used for commercial testing of PV modules.

\section{Materials and Methods}

\subsection{Materials}

In this work specially designed PV modules (Akhtar solar private limited company, Pakistan) were used. Silicon cells were sandwiched between ethylene vinyl acetate (EVA) sheets that acted as encapsulant. The front and back covers were comprised of $3.2 \mathrm{~mm}$ thick tempered glass and Tedlar, respectively. These layers were held together with an aluminum frame that gives them support mechanically. The PV modules were differentiated and named based on the type of cell (monocrystalline and polycrystalline) and the number of busbars (3 and 4), such as monocrystalline with 3 busbars (MT-3BB), monocrystalline with 4 busbars (MT-4BB), polycrystalline with 3 busbars (PT-3BB) and polycrystalline with 4 busbars (PT-4BB). The important rated specifications of the PV modules are given in Table 1.

\subsection{Apparatus Description}

A custom-made mechanical test rig was designed and manufactured to apply a simulated snow load on the PV modules in accordance with international standards ASTM E1830-15 and IEC 61215. The basic working principal and working components of this novel test setup are shown in Figure 1. The wind and snow loads were simulated using an inflated airbag, which assisted in imparting a homogenous load to the surface of the PV modules during the testing process. Load cells and pressure gauges were attached to the setup to ensure the uniformity of the applied load on PV modules while testing. The airbag used in this study was made of an anti-burst PVC plastic. It was designed to take the load of $6000 \mathrm{pa}$, with the factor of safety of 5 . The rigid frame of the test setup was fabricated from mild steel while polycarbonate sheets were used for the pressure chamber. The 3D design and fabricated setup highlighting the main components is shown in Figure 2.

Table 1. Detail specifications of the photovoltaic modules used in this study.

\begin{tabular}{cc}
\hline Name & Value \\
\hline Maximum Power $\left(P_{\max }\right)$ & $18 \mathrm{~W}$ \\
Maximum power voltage $(V m p)$ & $2.12 \mathrm{~V}$ \\
Maximum Power current $(I m p)$ & $8.20 \mathrm{~A}$ \\
Short Circuit Current $(I s c)$ & $8.35 \mathrm{~A}$ \\
Open Circuit Voltage $($ Voc $)$ & $2.50 \mathrm{~V}$ \\
Cell area $(A c)$ & $9.923 \mathrm{~cm}^{2}$ \\
Total module area $(A)$ & $15.71 \mathrm{~cm}^{2}$ \\
\hline
\end{tabular}




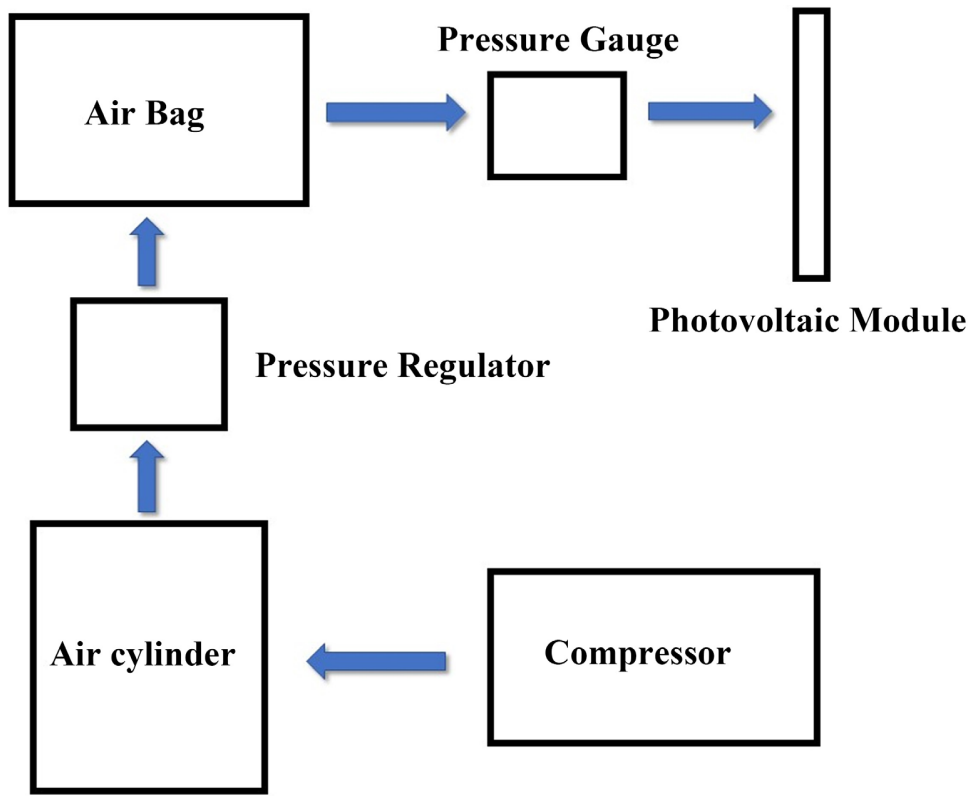

Figure 1. Block diagram representing different components of the novel pneumatic airbag testing setup for application of load on photovoltaic modules.

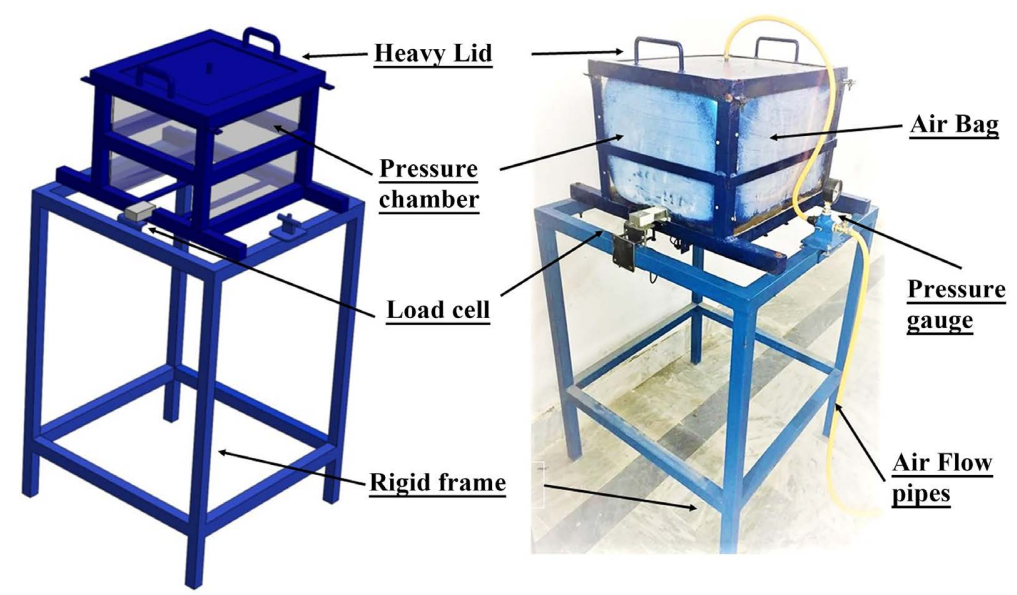

Figure 2. Showing different working components of the mechanical load test setup 3D diagram (left) and actual fabricated setup (right).

\subsection{Validation and Testing}

Pressure (approx. 5400 Pa) was applied for $3 \mathrm{hrs}$ on the front surface of PV modules with different number of busbars and cell type using the pneumatic airbag test setup. According to ASTM and IEC standards, this pressure is equal to simulated snow load on the PV modules throughout its lifetime [2] [20]. In the meantime, load data was carefully monitored from the attached load cell and pressure gauges after every $15 \mathrm{~min}$ interval to ensure uniformity of pressure. In order to get the average effect of the load, three PV modules from each type were tested according to the scheme showing in Figure 3(a). PV modules were visually inspected with naked eyes before and after the testing to find any visible damages to the modules. 
(a)

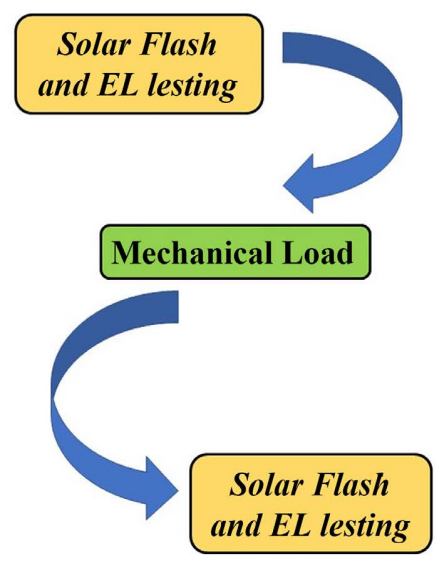

(b)

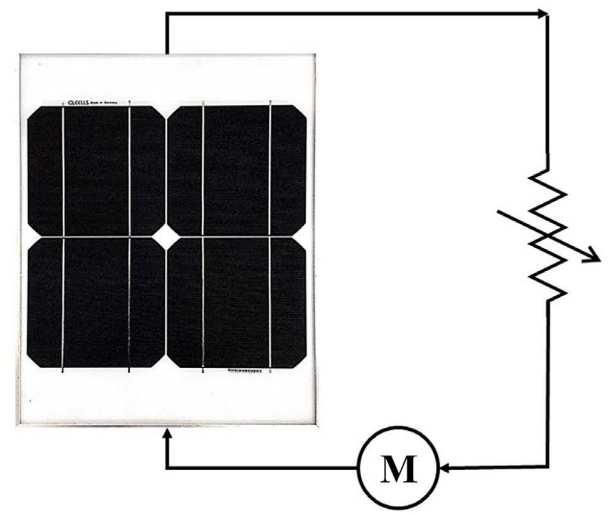

Figure 3. (a) Methodology used for mechanical testing for photovoltaic modules; (b) Electric circuit diagram designed for solar flash testing of photovoltaic modules before and after the introduction of applied loads.

Electroluminescence (EL) imaging tests were performed on the PV modules before and after the application of load. EL imaging is used to highlight the cracks and damaged cells present in the PV modules after the application of mechanical load. A crack or flaw in the solar cells is visible on an EL image because the input current is unable to reach the cracked parts of the cell in order to generate the luminescence effect, and as a result, the cracked regions of the cell look dark on the image. These testing were performed on an EL tester under conventional testing settings, according to the manufacturer at standard testing conditions. Because the light emitted is in the infra-red range, an infra-red CCD camera was used to detect the images [21]. Finally, the gathered observations were scrutinized in order to determine the influence of load on the mechanical breakdown of photovoltaic cells.

Solar flash test was used to measure the accurate output performance parameters of PV modules before and after the application of simulated snow load [22]. A special testing setup was designed for solar flash test based on IEC 60904-1 standards as show in the circuit diagram (Figure 3(b)). One end of the photovoltaic module was attached to a sliding rheostat (UNI-T, UT33C, China), while the other end was connected to a multimeter when performing solar flash testing as shown in Figure 3(b). The short circuit current (Isc) and the open circuit voltage ( $V o c$ ) was determined while changing the resistance of the module. Solar irradiance level was calculated using a TES, 1333 solar power meter. Infrared thermometer was used to measure the temperature and humidity levels at the time of testing.

Important electrical performance parameters were determined from solar flash tests. Maximum power output was calculated before and after the application of load using the following Equation (1):

$$
P=I \times V
$$


where " $P$ " is the maximum current drawn from the PV module, and " $V$ " is the maximum voltage generated during the solar flash tests. Similarly, the efficiency of the PV modules was determined using the following Equation (2):

$$
\eta=P /(E \times A)
$$

In this equation " $P$ ' is the maximum power output of the PV module at a given solar irradiance level of " $E$ ". Where " $A$ " is the total area of the module. Another important electrical parameter in the overall performance of PV module is fill factor. Fill factor was calculated from the following Equation (3), also reported in literature as shown:

$$
F F=P /(\operatorname{Voc} \times I S C)=(\eta \times A \times E) /(\operatorname{Voc} \times I s c)
$$

Here "Voc" is the open circuit voltage and "Isc" is the short circuit current determined through the solar flash test. The resistance offered to the flow of current is also an important parameter for the reliability of PV modules. It is usually known as series resistance of the PV modules and is determined using the following Equation (4), according to ASTM standards:

$$
\text { Rs }=\text { Vbias } / \text { Ibias }
$$

where "Vbias" is equal to Voc \pm 0.5 , and "Ibias" is calculated as the $3 \%$ of Isc of the PV modules. In addition, statistical analysis was conducted using a student's t-test for two tailed distributions with unequal variance. Significant was given to $\mathrm{p}$ value of less than 0.05 .

\section{Results and Discussions}

A uniform static load was applied to the surface of the PV modules for a period of 3 hrs. Pressure gauge and load cell data were acquired after every $15 \mathrm{~min}$ interval, to investigate the uniformity and continuity of the applied load throughout the duration of the test. Except for the running-in effect at the very start, where the load suddenly dropped from $91.4 \mathrm{~kg}$ to $88.6 \mathrm{~kg}$, most of the data was stable and showed continuity until the end (Figure 4). The load cell data was more stable after every interval as compared to the pressure gauge.

In order to make a quantitative comparison, data from solar flash tests was analyzed to determine the different performance parameters of PV modules before and after the application of simulated snow load. Figure 5(a) shows the maximum power output of PV modules with different numbers of busbars. There was a significant decrease in power output after the application of load for all the tested PV modules ( $\mathrm{p}<0.05$ ). PT-3BB shows an $18 \%$ decrease in power output as compared to PT-4BB, which only shows a $9 \%$ decrease after the application of load. A similar trend was observed in monocrystalline modules, where the average power output decreased by $13 \%$ with 4 busbars compared to $19 \%$ with 3 busbar PV modules. On the other hand, polycrystalline modules showed a lesser combined effect of $27 \%$ on the decrease in power output as compared to $32 \%$ in monocrystalline modules. Similar trends were observed for the efficiency of the PV modules before and after the application of simulated snow load as shown 


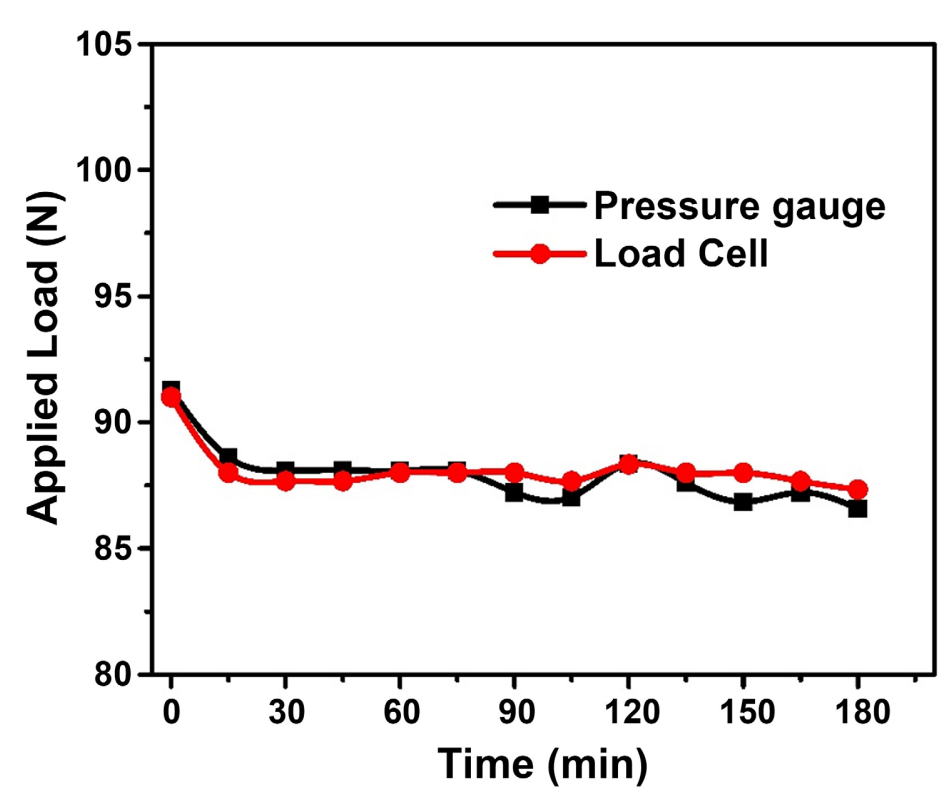

Figure 4. Comparison of load between the pressure gauge and load cell readings on the surface of photovoltaic modules at different time intervals in a total of $3 \mathrm{hrs}$ cycle.

(a)

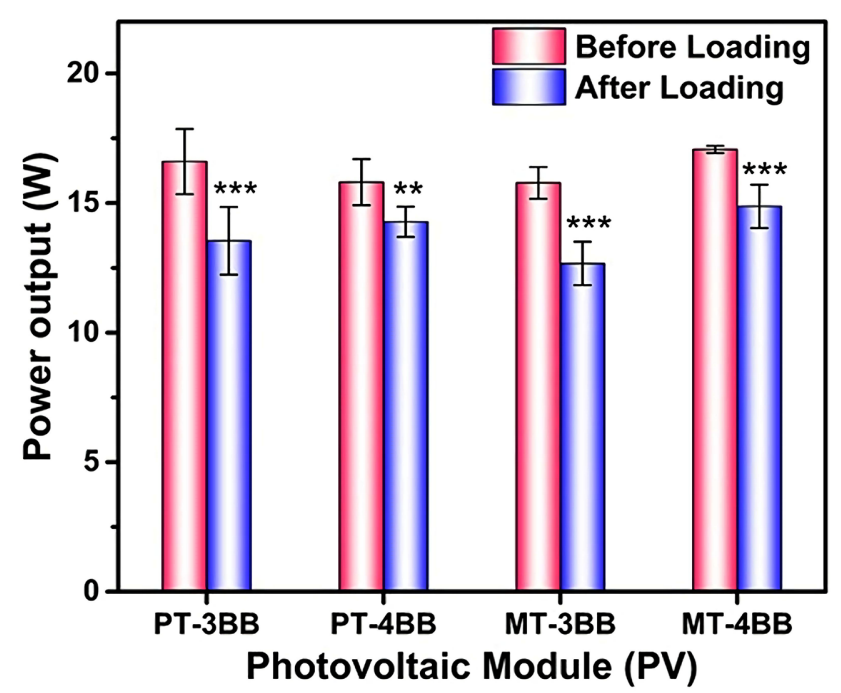

(b)

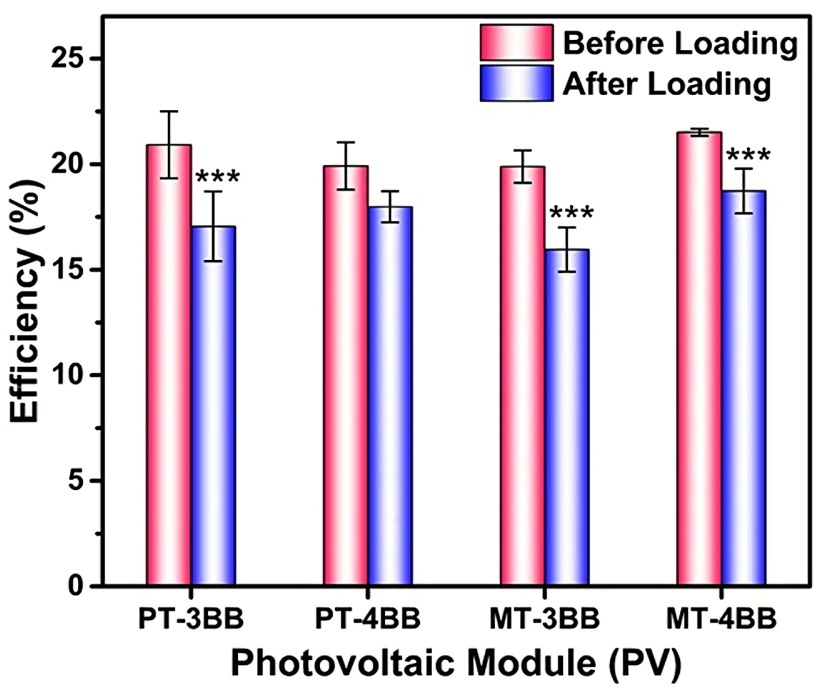

Figure 5. Showing (a) Power and (b) Efficiency of different types of photovoltaic modules before and after the introduction of applied loads.

in Figure 5(b). However, the efficiency was still greater than 15\% for all types of PV modules. A minimum decrease of $9 \%$ in efficiency was observed in PT-4BB as compared to a maximum decrease of $20 \%$ in MT-3BB modules.

In an effort to scrutinize the overall performance of the different types of PV modules, fill factor and series resistance were determined as shown in Figure 6(a) and Figure 6(b), respectively. MT-4BB showed the highest fill factor of $82 \%$ $\pm 0.65 \%$ among the tested modules, which was still the highest after the application of load with $71 \% \pm 4.03 \%$. Unlike the MT-3BB, which shows the lowest fill 
(a)

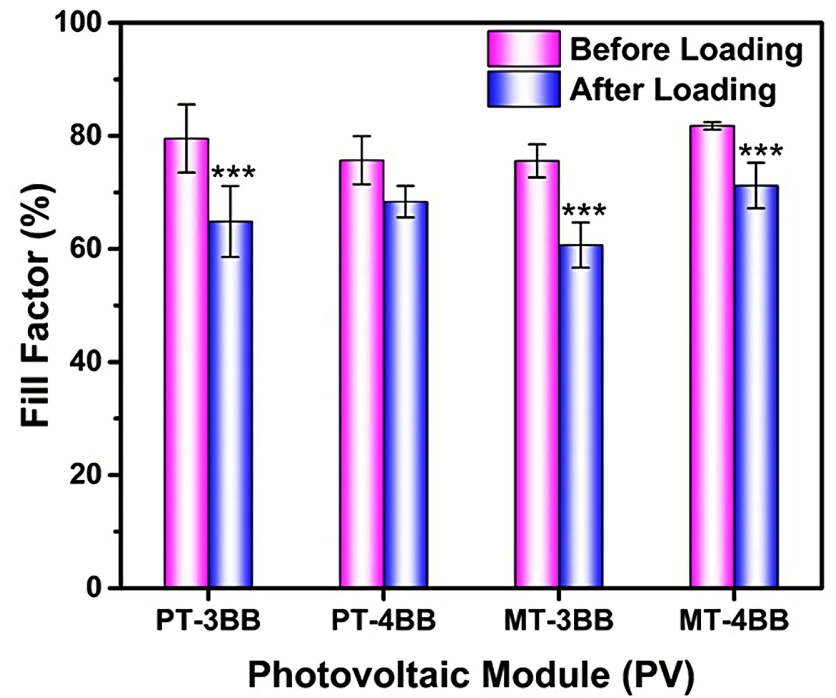

(b)

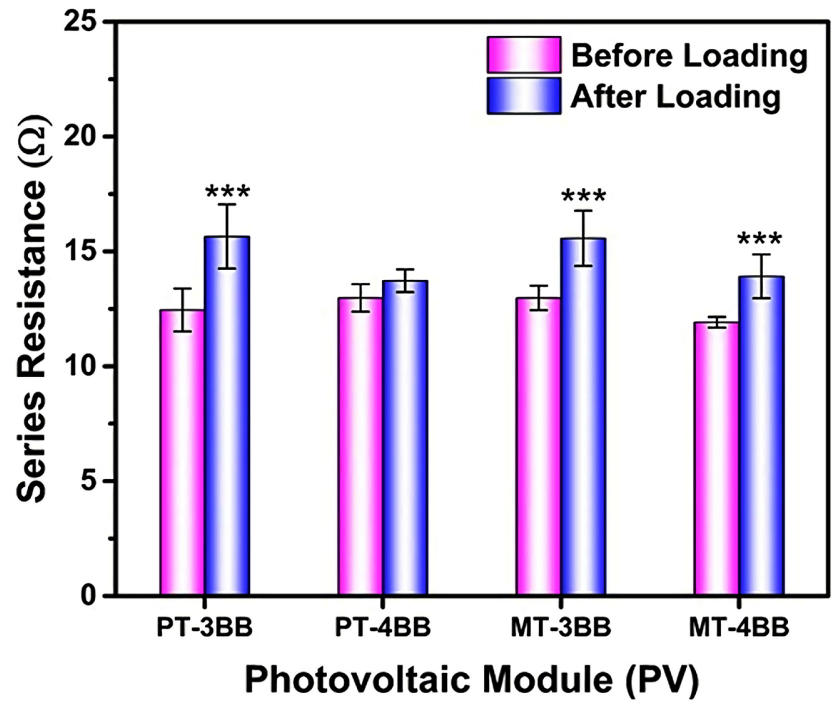

Figure 6. Showing (a) Fill factor and (b) Series resistance of different types of photovoltaic modules before and after the application of mechanical load.

factor of $60 \% \pm 3.99 \%$ after the application of load. Besides, there was a significant difference in fill factor for all types of modules before and after the introduction of applied loads $(\mathrm{p}<0.05)$, as shown in Figure 6(a). In contrast, series resistance was significantly increased $(\mathrm{p}<0.05)$ for PT-3BB, MT-3BB and MT-4BB modules after the application of load, as compared to PT-4BB ( $p>0.05)$, as depicted in Figure $6(\mathrm{~b})$. The maximum increase of $20 \%$ was observed in PT-3BB modules. Interestingly, the difference between the series resistance of monocrystalline PV modules was observed to be only $2 \%$ among 3 and 4 busbar modules.

The electrical performance of PV modules before and after the application of simulated snow load was quantified through a widely used solar flash test [23]. The power output and efficiency of a module are determined by a variety of parameters, including the amount of irradiance received, the reflectivity of the glass used, the manufacturing process for fabrication, and the mechanical integrity of the module [24]. In addition, compared to commercially available modules, the efficiency of the PV modules employed in this study was significantly higher. Because the modules we used were manufactured only for testing purposes in a controlled environment. Our results confirm the significant $(\mathrm{p}<0.05)$ effect of snow load on the electrical performance of PT-3BB, MT-3BB and MT$4 \mathrm{BB}$ as shown in Figure 5. However, the effect was less significant in the case of PT-4BB modules. The reason behind this lies in the different manufacturing processes of these solar cells. For example, silicon is shaped into bars and then sliced into wafers to be used in the production of monocrystalline solar cells. Instead, in order to create cells for polycrystalline panels, bits of silicon are fused together to form wafers, which can further strengthen the ability of PV module to withstand environmental mechanical stress [5]. Compared to monocrystal- 
line, the polycrystalline modules have a lower production cost, due to less waste generated during manufacturing and lower energy consumption [3].

In order to investigate the decline in performance parameters of the PV module after the application of load, EL testing was performed. The output images of these tests are shown in Figure 7(a) and Figure 7(b) for monocrystalline and polycrystalline PV modules, respectively. Expectedly, there were a number of cracks and damaged cells that appeared after the application of load. The monocrystalline PV modules show big black regions/inactive cells after the application of load. Some of the cracks observed in MT- $4 \mathrm{BB}$ were angled at $\pm 45^{\circ}$ to the busbars, as highlighted by the red line in Figure 7(a). The cells in the MT-3BB PV module were mostly damaged and became inactive after the testing, as shown in Figure 7(a). In contrast, there was rather a smaller number of cracks and damaged cells observed in the polycrystalline PV modules after testing. In PT-3BB and PT-4BB modules, many of the cracks that appeared were at the edges of the solar cells and near the busbars, as compared to the center of the cells, which are encircled in red as depicted in Figure 7(b).

The simulated static snow load was applied, as it had a significant impact on the size and intensity of the cracks primarily through two mechanisms: it assisted the propagation of existing cracks in the modules and prompted the start of new cracks. The EL images clearly showed the expansion of existing cracks in the modules as a result of the application of simulated load. Furthermore, the alignment of these cracks with respect to the busbars has been shown to have a considerable impact on the rise in series resistance of the PV modules [25]. As

\section{Before Loading}
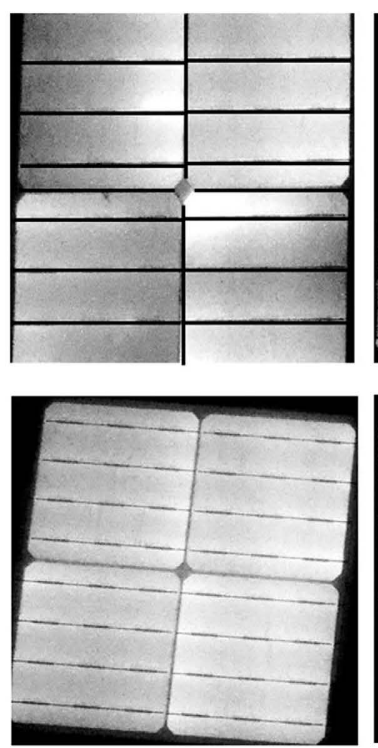

(a)
After Loading
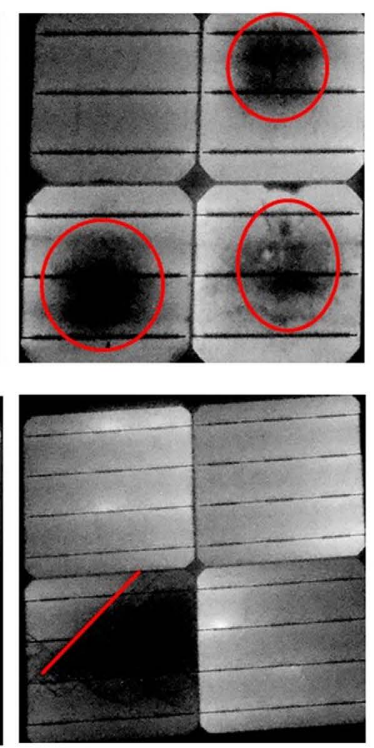

\section{Before Loading}
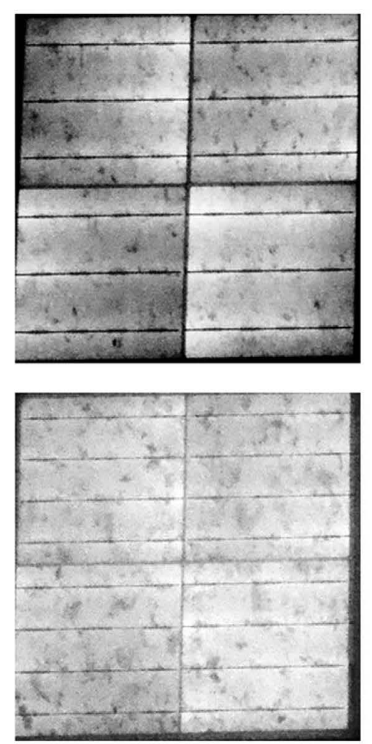

After Loading
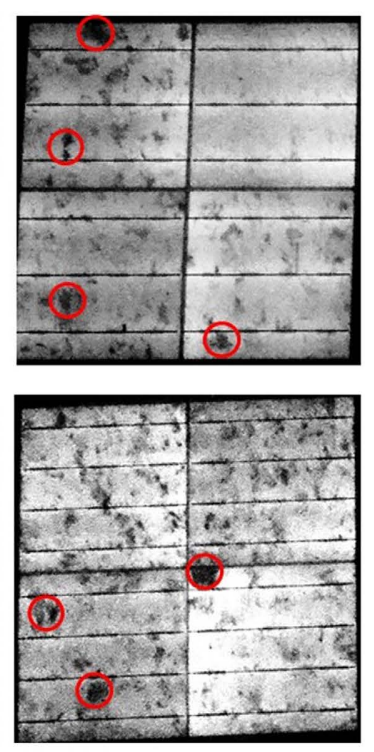

(b)

Figure 7. Electro luminance images of (a) Monocrystalline and (b) Polycrystalline photovoltaic modules before and after the application of external load. Red circles indicate the damaged cells in the modules, while the red line shows a $45^{\circ}$ crack in the modules appeared after loading. 
stated previously, cracks that run parallel to the busbars cause a significant increase in electrical resistance, but cracks that run diagonally to the busbars have only a minor impact on the power output [26] [27]. Several rectangular dark or black patches were also seen in the EL images captured after the mechanical testing was done, which were then analyzed. These zones are formed as a result of the formation of micro cracks that are less visible, but when forces are applied to them, they expand and cause harm to the surrounding cells.

Consequently, raising the resistance of the fingers occurs due to the fact that such regions appear as dark areas in the EL images [17] [28]. These results are in line with the computer simulated studies using stress analysis on PV modules [29]. Furthermore, improvements in polycrystalline technology over the past few years are due to the development of high-performance polycrystalline silicon cells, which have fewer structural defects as compared to monocrystalline [30] [31]. According to previous studies, EL images of solar cells shows cells with a comparable structure of shapes and sizes [21] [32]. Hence, proving the efficacy of the newly developed test setup by bringing changes to the output performance of PV modules.

The limitations of this study include that the different PV modules tested in this study are only prototypes and especially made on request. However, this may not alter the effectiveness of the newly developed test setup. A further study is needed to demonstrate the effect of load on commercially available modules using this equipment. A newly developed pneumatic testing setup is demonstrated to have effectively characterized PV modules based on their mechanical integrity and electrical performance.

\section{Conclusion}

An indigenously designed pneumatic airbag test setup was developed to evaluate the performance of different PV modules under static snow loads. A simulated snow load of $5400 \mathrm{~Pa}$ was uniformly applied to the surface of monocrystalline and polycrystalline modules having 3 and 4 busbars, respectively. The EL images before and after the application of load show that cracks were generated in the modules due to the load. The types of cracks observed were mostly randomly oriented, while some were at $\pm 45^{\circ}$ to the busbars. These cracks have resulted in damaged cells, hence reducing the output electrical performance. A notable drop in different performance parameters such as power, efficiency and fill factor were observed. However, the series resistance offered to the flow of current was significantly increased for monocrystalline modules. Finally, it is suggested that PV module manufacturers be encouraged to evaluate the key aspects during production of modules in order to achieve better performance throughout their lifespan.

\section{Acknowledgements}

The authors would like to acknowledge the support by USAID center for ad- 
vanced studies in energy, UET Peshawar, Pakistan.

\section{Conflicts of Interest}

The authors declare that they have no known competing financial interests or personal relationships that could have appeared to influence the work reported in this paper

\section{References}

[1] Woolard, E. and Tan, T.C. (2013) Development of a Mechanical Finite Element Model Utilising Module Displacement Test Data to Optimise the Module Design for an Applied Load. Energy Procedia, 33, 272-279. https://doi.org/10.1016/j.egypro.2013.05.068

[2] Zhang, C., Zhang, Y., Su, J., Gu, T. and Yang, M. (2020) Modeling and Prediction of PV Module Performance under Different Operating Conditions Based on PowerLaw I-V Model. IEEE Journal of Photovoltaics, 10, 1816-1827. https://doi.org/10.1109/JPHOTOV.2020.3016607

[3] Lewis, N.S. (2007) Toward Cost-Effective Solar Energy Use. Science, 315, 798-801. https://doi.org/10.1126/science.1137014

[4] Kilikevičius, A., Čereška, A. and Kilikevičienè, K. (2016) Analysis of External Dynamic Loads Influence to Photovoltaic Module Structural Performance. Engineering Failure Analysis, 66, 445-454. https://doi.org/10.1016/j.engfailanal.2016.04.031

[5] Parida, B., Iniyan, S. and Goic, R. (2011) A Review of Solar Photovoltaic Technologies. Renewable and Sustainable Energy Reviews, 15, 1625-1636. https://doi.org/10.1016/j.rser.2010.11.032

[6] Nayak, P.K., Mahesh, S., Snaith, H.J. and Cahen, D. (2019) Photovoltaic Solar Cell Technologies: Analysing the State of the Art. Nature Reviews Materials, 4, 269-285. https://doi.org/10.1038/s41578-019-0097-0

[7] Amalu, E.H., Hughes, D.J., Nabhani, F. and Winter, J. (2018) Thermo-Mechanical Deformation Degradation of Crystalline Silicon Photovoltaic (c-Si PV) Module in Operation. Engineering Failure Analysis, 84, 229-246. https://doi.org/10.1016/j.engfailanal.2017.11.009

[8] Klugmann-Radziemska, E. and Rudnicka, M. (2020) Decrease in Photovoltaic Module Efficiency Because of the Deposition of Pollutants. IEEE Journal of Photovoltaics, 10, 1772-1779. https://doi.org/10.1109/JPHOTOV.2020.3013971

[9] Shah, N.A. (2018) Development of Specially Designed Pneumatic Setup for Mechanical Testing of Photovoltaic Modules. Department of Mechanical Engineering, University of Engineering and Technology, Peshawar, 85.

https://doi.org/10.13140/RG.2.2.31742.92486

[10] Nouman Ali Shah, R.M.G., Noman, M., Zafar, F.U., Khan, A.H. and Saeed, R. (2017) Mechanical Testing and Failure Analysis of Photovoltaic Modules. National Conference on Green Energy Technologies, Peshawar, 18 May 2017. https://doi.org/10.13140/RG.2.2.30222.48960

[11] Ferrara, C. and Philipp, D. (2012) Why Do PV Modules Fail? Energy Procedia, 15, 379-387. https://doi.org/10.1016/j.egypro.2012.02.046

[12] Lee, Y. and Tay, A.A.O. (2013) Stress Analysis of Silicon Wafer-Based Photovoltaic Modules under IEC 61215 Mechanical Load Test. Energy Procedia, 33, 265-271. https://doi.org/10.1016/j.egypro.2013.05.067 
[13] Roy, S., Kumar, S. and Gupta, R. (2019) Investigation and Analysis of Finger Breakages in Commercial Crystalline Silicon Photovoltaic Modules under Standard Thermal Cycling Test. Engineering Failure Analysis, 101, 309-319. https://doi.org/10.1016/j.engfailanal.2019.03.031

[14] Makarskas, V., Jurevičius, M., Zakis, J., Kilikevičius, A., Borodinas, S., Matijošius, J. and Kilikevičienè, K. (2021) Investigation of the Influence of Hail Mechanical Impact Parameters on Photovoltaic Modules. Engineering Failure Analysis, 124, Article ID: 105309. https://doi.org/10.1016/j.engfailanal.2021.105309

[15] Nouman Ali Shah, A.H.K., Zafar, F.U., Noman, M. and Gul, R.M. (2017) Effect of Wind Load on the Performance of Photovoltaic (PV) Modules. International Conference on Sustainable Energy Technologies, Islamabad, 12-13 September 2017. https://doi.org/10.13140/RG.2.2.33577.93289

[16] Gul, R.M., Kamran, M.A., Zafar, F.U. and Noman, M. (2020) The Impact of Static Wind Load on the Mechanical Integrity of Different Commercially Available MonoCrystalline Photovoltaic Modules. Engineering Reports, 2, e12276. https://doi.org/10.1002/eng2.12276

[17] Sander, M., Dietrich, S., Pander, M., Ebert, M. and Bagdahn, J. (2013) Systematic Investigation of Cracks in Encapsulated Solar Cells after Mechanical Loading. Solar Energy Materials and Solar Cells, 111, 82-89. https://doi.org/10.1016/j.solmat.2012.12.031

[18] Du, Y., Wang, L. and Tao, W. (2020) Modeling, Imaging and Resistance Analysis for Crystalline Silicon Photovoltaic Modules Failure on Thermal Cycle Test. Engineering Failure Analysis, 118, Article ID: 104818. https://doi.org/10.1016/j.engfailanal.2020.104818

[19] Sidibba, A., Ndiaye, D., El Bah, M. and Bouhamady, S. (2018) Analytical Modeling and Determination of the Characteristic Parameters of the Different Commercial Technologies of Photovoltaic Modules. Journal of Power and Energy Engineering, 6, 14-27. https://doi.org/10.4236/jpee.2018.63002

[20] Abu-Rahmeh, T.M. (2017) Efficiency of Photovoltaic Modules Using Different Cooling Methods: A Comparative Study. Journal of Power and Energy Engineering, 5, 32-45. https://doi.org/10.4236/jpee.2017.59003

[21] Mantel, C., Villebro, F., Parikh, H.R., Spataru, S., Benatto, G.A.d.R., Sera, D., Poulsen, P.B. and Forchhammer, S. (2020) Method for Estimation and Correction of Perspective Distortion of Electroluminescence Images of Photovoltaic Panels. IEEE Journal of Photovoltaics, 10, 1797-1802. https://doi.org/10.1109/JPHOTOV.2020.3019949

[22] Herman, M., Jankovec, M. and Topič, M. (2012) Optimal I-V Curve Scan Time of Solar Cells and Modules in Light of Irradiance Level. International Journal of Photoenergy, 2012, 151452-151463. https://doi.org/10.1155/2012/151452

[23] Kurchin, R.C., Poindexter, J.R., Vahanissi, V., Savin, H., del Canizo, C. and Buonassisi, T. (2020) How Much Physics Is in a Current-Voltage Curve? Inferring Defect Properties from Photovoltaic Device Measurements. IEEE Journal of Photovoltaics, 10, 1532-1537. https://doi.org/10.1109/JPHOTOV.2020.3010105

[24] Sinha, A., Sastry, O.S. and Gupta, R. (2016) Nondestructive Characterization of Encapsulant Discoloration Effects in Crystalline-Silicon PV Modules. Solar Energy Materials and Solar Cells, 155, 234-242. https://doi.org/10.1016/j.solmat.2016.06.019

[25] Munoz, M.A., Alonso-García, M.C., Vela, N. and Chenlo, F. (2011) Early Degradation of Silicon PV Modules and Guaranty Conditions. Solar Energy, 85, 2264-2274. https://doi.org/10.1016/j.solener.2011.06.011 
[26] Morlier, A., Haase, F. and Kontges, M. (2015) Impact of Cracks in Multicrystalline Silicon Solar Cells on PV Module Power-A Simulation Study Based on Field Data. IEEE Journal of Photovoltaics, 5, 1735-1741. https://doi.org/10.1109/JPHOTOV.2015.2471076

[27] Popovich, V.A., Yunus, A., Janssen, M., Richardson, I.M. and Bennett, I.J. (2011) Effect of Silicon Solar Cell Processing Parameters and Crystallinity on Mechanical Strength. Solar Energy Materials and Solar Cells, 95, 97-100. https://doi.org/10.1016/j.solmat.2010.04.038

[28] Kajari-Schršder, S., Kunze, I. and Kšntges, M. (2012) Criticality of Cracks in PV Modules. Energy Procedia, 27, 658-663. https://doi.org/10.1016/j.egypro.2012.07.125

[29] Shah, N.A. (2017) Mechanical Integrity Analysis of Photovoltaic Modules under Wind Loads Using Finite Element Simulations. International Conference on Aerospace Science and Engineering, Islamabad, 14-16 November 2017, 86-89.

[30] Lan, C.W., Lan, A., Yang, C.F., Hsu, H.P., Yang, M., Yu, A., Hsu, B., Hsu, W.C. and Yang, A. (2017) The Emergence of High-Performance Multi-Crystalline Silicon in Photovoltaics. Journal of Crystal Growth, 468, 17-23.

https://doi.org/10.1016/j.jcrysgro.2016.10.072

[31] Yang, Y.M., Yu, A., Hsu, B., Hsu, W.C., Yang, A. and Lan, C.W. (2015) Development of High-Performance Multicrystalline Silicon for Photovoltaic Industry. Progress in Photovoltaics: Research and Applications, 23, 340-351. https://doi.org/10.1002/pip.2437

[32] Dhimish, M. and Lazaridis, P.I. (2021) An Empirical Investigation on the Correlation between Solar Cell Cracks and Hotspots. Scientific Reports, 11, Article No. 23961. https://doi.org/10.1038/s41598-021-03498-Z 